\title{
Arsenic immunotoxicity: a review
}

\author{
Nygerma L Dangleben ${ }^{1}$, Christine F Skibola ${ }^{2}$ and Martyn T Smith ${ }^{1 *}$
}

\begin{abstract}
Exposure to arsenic (As) is a global public health problem because of its association with various cancers and numerous other pathological effects, and millions of people worldwide are exposed to As on a regular basis. Increasing lines of evidence indicate that As may adversely affect the immune system, but its specific effects on immune function are poorly understood. Therefore, we conducted a literature search of non-cancer immune-related effects associated with As exposure and summarized the known immunotoxicological effects of As in humans, animals and in vitro models. Overall, the data show that chronic exposure to As has the potential to impair vital immune responses which could lead to increased risk of infections and chronic diseases, including various cancers. Although animal and in vitro models provide some insight into potential mechanisms of the As-related immunotoxicity observed in human populations, further investigation, particularly in humans, is needed to better understand the relationship between As exposure and the development of disease.
\end{abstract}

Keywords: Arsenic, Immune system, Immunotoxicity, Immunocompromised, Immunosuppression

\section{Background}

Exposure to arsenic (As) is a global public health concern because As is widely distributed and associated with numerous adverse effects. As is a well-established cause of skin, lung and bladder cancers in humans [1], and is associated with skin lesions, diabetes, cardiovascular disease and other disorders [1-3]. Well over 100 million people worldwide are exposed to As, particularly through ingestion of contaminated food and water in countries such as India, Bangladesh, Taiwan, Chile, and the United States [1,4]. Exposures also occur through inhalation, especially in agricultural and industrial settings [4].

Inorganic As exists in the environment as arsenite $\left(\mathrm{As}^{\mathrm{III}}\right)$ or arsenate $\left(\mathrm{As}^{\mathrm{V}}\right)$ and is metabolized in humans via conversion of $\mathrm{As}^{\mathrm{V}}$ to $\mathrm{As}^{\mathrm{III}}$ with subsequent methylation to mono- and di-methylated arsenicals (MMA and DMA, respectively) [5]. $\mathrm{MMA}^{\mathrm{III}}$ is considered the most toxic arsenical in vitro [6-9] and individuals who excrete a higher proportion of ingested As as urinary MMA have increased risks of As-associated cancers [10,11], suggesting a key role for MMA in As toxicity. Proposed mechanisms of toxicity include oxidative stress, inhibition of DNA repair, chromosomal aberrations, micronuclei formation, induction of apoptosis, modification of cellular signaling via altered activation, expression and DNA binding activity of transcription factors, epigenetic modifications resulting in aberrant gene expression, and altered phenotype of stem cell populations [12-16]. As toxicity is thus complex and multifaceted, but is not yet well understood.

Although extensive research has focused on investigating As carcinogenicity, growing evidence indicates that As also has deleterious effects on the immune system $[17,18]$. This may potentially play a role in As carcinogenesis of various tissues through reduced immune surveillance. However, the specific effects of As on immune function remain poorly understood. Therefore, we considered that further investigation of As immunotoxicity is warranted and conducted a PubMed search of As exposure and non-cancer immune-related effects through October 2012. Here, we summarize the known toxicological effects of As on immune function in humans, laboratory animals and in vitro models, and identify possible future research directions to help close the gaps in knowledge.

\footnotetext{
* Correspondence: martynts@berkeley.edu

'Division of Environmental Health Sciences, School of Public Health,

University of California, Berkeley, CA 94720, USA

Full list of author information is available at the end of the article
}

C Biomed Central

(c) 2013 Dangleben et al.; licensee BioMed Central Ltd. This is an Open Access article distributed under the terms of the Creative Commons Attribution License (http://creativecommons.org/licenses/by/2.0), which permits unrestricted use, distribution, and reproduction in any medium, provided the original work is properly cited. 


\section{Epidemiological findings \\ Effects in adults Gene expression}

Microarray-based assays are widely used for identifying differentially expressed genes in investigations of As carcinogenicity. However, a limited number of reported epidemiological studies have employed this powerful method to investigate As toxicity in immune cells from otherwise healthy persons. A microarray-based genomewide expression study of peripheral blood mononuclear cells (PBMC) from 21 subjects in New Hampshire whose drinking-water As averaged $0.7 \mu \mathrm{g} / \mathrm{L}$ (range 0.007-5.3 $\mu \mathrm{g} / \mathrm{L}$, $n=10$ ) and $32 \mu \mathrm{g} / \mathrm{L}$ (range 10.4-74.7 $\mu \mathrm{g} / \mathrm{L}, n=11$ ) showed significant differences between exposure groups in transcripts with functions in T-cell receptor signaling, cell cycle regulation and apoptosis, and most strikingly defense and immune response [19]. Notably, higher As exposure was associated with increased expression of killer cell immunoglobulin-like receptors that inhibit natural killer cell-mediated cytotoxicity, as well as decreased expression of MHC class II molecules, HLA-DQB1, HLA$D P A 1$, and $H L A-D R B 1$; defense response genes, CD69, $H S P A 9 B$ and MALT1; and inflammatory genes, IL2RA and $I L 1 B$ [19]. Exposure was determined by levels of drinking-water As combined with urinary or toenail As as internal markers of exposure, and control and exposed subjects were matched for age, sex and smoking status.

Down-regulated $I L 1 B$ was also identified in a microarray study of PBMC from an As-exposed Bangladeshi population with $(n=11)$ and without skin lesions $(n=5)$ [20]. An overall suppression of 467/468 differentially expressed genes was observed. These findings contradict those from a microarray analysis of PBMC from 24 individuals in Taiwan with low $(0-4.32 \mu \mathrm{g} / \mathrm{L})$, intermediate (4.64-9 $\mu \mathrm{g} / \mathrm{L})$, and high $(9.6-46.5 \mu \mathrm{g} / \mathrm{L})$ blood As levels [21]. Among 62/708 significantly altered genes were several inflammatory molecules that were up-regulated, including IL1B, IL6, CCL2 and CD14, indicating that prolonged exposure may induce ongoing inflammation that could contribute to As-associated disease [21].

More recently, a cDNA microarray study of PBMC from 10 individuals in Mexico having urinary As levels between 117.23 and $435.12 \mathrm{mg} / \mathrm{g}$ creatinine $(n=5)$ revealed significant differences in expression of apoptosisand inflammation-related genes compared to unexposed subjects $(n=5)$ [22]. Exposure was associated with down-regulated inflammatory genes, including TNF, IL11, IL1ORB, CCR1, and CXCL2 [22], which is in stark contrast with up-regulated inflammatory genes reported in chronically-exposed persons in Taiwan [21]. However, the finding of decreased TNF concurs with data from the Bangladeshi study [20]. Some apoptosis-related genes were significantly up-regulated, including BCL2L1 and CASP2, whereas others, namely TRAIL and FASLG, were suppressed [22]. Such contradictory results could be influenced by differences in exposures, sampling, methodology, population genetics and/or environmental factors. For instance, the Mexican study [22] analyzed individual RNA samples from each subject, whereas the Taiwanese study [21] used pooled samples. Additionally, the small number of participants may not be large enough to draw definitive conclusions.

One caveat is that changes in expression may not necessarily be viewed as toxic responses; some changes may occur following chemical exposure as adaptive responses, e.g. acquired resistance to acute toxicity, over time [23]. However, changes reported at the gene and/or protein level are provided to illustrate possible effects resulting from As exposure that may alter cellular function and ultimately the immune system's ability to defend the host.

\section{Lymphocyte activation}

Impaired T-cell activation and functional responses have been observed in As-exposed persons. Analysis of 11 exposed and 13 control individuals in Mexico indicated that chronic exposure significantly decreased proliferation of mitogen-stimulated lymphocytes [24], which is supported by a later study identifying delayed cell cycle progression from $\mathrm{S}$ - to $\mathrm{M}$-phase in chronically-exposed persons whose drinking-water levels averaged $412 \mu \mathrm{g}$ As/L compared with persons consuming water averaging $37.2 \mu \mathrm{g} \mathrm{As} / \mathrm{L}$ [25]. Similarly, a cross-sectional study in West Bengal, India of 18 controls and 20 As-exposed individuals with skin lesions found significant reductions in lymphoproliferation and Th1/Th2 secretion of IL-2, IL-4, IL-5, IL-10, IFN- $\gamma$ and TNF- $\alpha$ in As-exposed compared with unexposed individuals [26]. In contrast, lymphocytes from Chilean copper smelter workers exposed to Ascontaminated air $(n=40)$ displayed higher proliferation rates than those of As-unexposed individuals from the same region $(n=32)$ [27]. While reasons for the observed differential effects on T-cell proliferation remain unclear, it is plausible that differences in population genetics, metabolism, and/or exposure could be involved. The study also found that urinary As levels positively correlated with oxidative stress markers serum superoxide dismutase (SOD) and lymphocyte malondialdehyde (MDA), and negatively correlated with serum vitamin E levels, suggesting that chronic exposure induces lymphocyte oxidative damage [27].

\section{Lymphocyte subpopulations}

Increasing evidence indicates that As affects numerous immune cell subpopulations. Subjects exhibiting dermatological symptoms $(n=30)$ from exposure to $>100 \mu \mathrm{g}$ As $/ \mathrm{L}$ for $>10$ years in Eastern India demonstrated significantly increased eosinophil numbers and decreased monocyte 
counts compared to unexposed persons $(n=25)$ [28]. As also disrupts macrophage function: monocyte-derived macrophages from As-exposed individuals with skin lesions $(n=70)$ demonstrated cell rounding and significantly reduced adhesion, nitric oxide anion $\left(\mathrm{NO}^{-}\right)$production and phagocytic capacity compared to macrophages from non-exposed persons $(n=64)$ [29]. Down-regulated F-actin and CD54 adhesion molecule, and altered Rho A-ROCK signaling likely contributed to impaired macrophage function.

Investigation of As influence on immune regulation revealed that in chronically-exposed but otherwise healthy individuals $(n=47)$, urinary As levels (range, $8.1-448 \mu \mathrm{g} / \mathrm{g}$ creatinine) significantly inversely correlated with the number and function of natural $\mathrm{T}$ regulatory (nTreg) lymphocytes but not other regulatory T-cells [30]. nTreg lymphocytes are $\mathrm{CD} 25^{+} \mathrm{Foxp}^{+}{ }^{+} \mathrm{T}$-cells that constitute approximately $10 \%$ of circulating $\mathrm{CD}^{+}{ }^{+} \mathrm{T}$-cells and play a critical role in immune homeostasis by suppressing immune response [31]. Although increased apoptotic PBMC were evident in exposed subjects, no significant correlation was found with urinary As levels, suggesting that the effect on nTreg cells was not mediated by apoptosis induction [30]. Alternatively, this could be due to individual differences in As susceptibility. Exposure positively correlated with monocyte innate immune receptor complex TLR4/CD14 and TNF- $\alpha$ secretion [30], which may be causally associated with As effects on nTreg lymphocytes given their inhibitory effect on pro-inflammatory TNF- $\alpha$ release [32]. These results concur with previous findings that chronic human As exposure induces inflammation, including CD14 [21].

\section{Humoral immunity}

Studies evaluating antibody levels in As-exposed individuals yield conflicting results. One study observed no changes in serum IgM, IgA or IgG in 47 adult male workers exposed to As in a coal-burning power plant compared to 27 workers from another plant in the same district whose As coal content was $>10$ times lower [33]. It should be noted that exposure duration and internal As doses are unknown; thus, negative results could be due to acute or low-dose internal As levels. In contrast, Bangladeshi subjects $(n=125)$ chronically exposed to drinking-water As demonstrated significantly elevated serum IgA, IgG and IgE compared to unexposed persons [34]. IgG and IgE levels were significantly higher during initial stages of skin manifestations, and IgE continued to increase with prolonged exposure. Moreover, increased prevalence of respiratory complications including cough, chest sound, bronchitis and asthma were evident in exposed individuals, and mean serum IgE was higher in subjects with respiratory symptoms relative to exposed subjects without [34]. No effect on eosinophils was observed [34], in contrast with a reported As-associated increase in eosinophil numbers [28], suggesting that increased serum IgE may be due to direct inflammatory effects of As rather than allergic disease [34].

\section{Pulmonary effects}

Health outcomes of As immunosuppression are evidenced by increased prevalence of opportunistic infections such as tuberculosis and fungal and respiratory tract infections (RTI) $[26,29,35]$. A recent report from Chile revealed increased mortality from As-associated pulmonary tuberculosis [35]. Reports of As-associated pulmonary effects [26,29,34-36] support growing evidence indicating that long-term exposure increases risk of reduced lung function and non-malignant lung disease [36-41]. Moreover, epidemiological investigations provide compelling evidence that As increases the incidence of bronchiectasis [42,43], a pulmonary disease characterized by chronic infection, inflammation, irreversible bronchial damage, and respiratory failure [44,45]. Chronically-exposed subjects from West Bengal, India with As-related skin lesions $(n=108)$ demonstrated a 10-fold higher prevalence of bronchiectasis compared with subjects without lesions $(n=150)$ [42]. A later report from Chile indicated elevated mortality rates for bronchiectasis in adults aged 30-49 resulting from early-life As exposure; compared with controls, mortality rates for those with childhood and in utero exposure were 12- and 46-fold higher, respectively [43]. Also observed were 6- to 7-fold increases in lung cancer mortality rates resulting from early-life exposures. Studies on this As-exposed Chilean population indicate long latency patterns of increased lung, kidney and bladder cancer mortality continuing for $>25$ years after exposures ended $[46,47]$. Overall, these reports indicate that As not only exerts severe respiratory effects, but that early-life exposures have pronounced long-term consequences that may include higher prevalence of and mortality from cancers of different tissues. Intriguingly, women appear to be somewhat protected from skin and respiratory manifestations [36,48], possibly due to sex hormonerelated increased methylation capacity of As in women than in men [49].

\section{HBD1 involvement}

Interestingly, we previously reported in two As-exposed populations from Nevada and Chile a significant inverse correlation in men between urinary levels of As and antimicrobial peptide human $\beta$-defensin-1 (HBD1) [50]. Studies suggest a primary role for HBD1 against pulmonary pathogens relevant to bronchiectasis $[44,45]$ and an association between HBD1 antimicrobial inactivation and recurrent airway infections in cystic fibrosis patients 
$[51,52]$. Further, observations from transgenic mice deficient in the mouse ortholog of HBD1 indicate that $\beta$-defensin-1 serves as an initial barrier to pulmonary bacterial colonization [53]. Given growing evidence that $D E F B 1$, the gene encoding HBD1, is a putative tumor suppressor whose down-regulation may be involved in tumorigenesis of multiple tissues [54-62], it is tempting to speculate that $\mathrm{HBD} 1$ suppression may contribute to As-induced carcinogenesis or bronchiectasis. Although our ongoing studies demonstrate As-induced reductions in DEFB1 mRNA and protein in human cell lines (unpublished data), confirmatory evidence of HBD1 inhibition is needed from other As-exposed populations. Thus, it remains to be determined whether HBD1 is suppressed in lungs of As-exposed individuals, and further investigations are needed to elucidate the role of down-regulated HBD1 in As immunotoxicity and carcinogenicity.

\section{Effects in children and infants}

The fetus, infant and young child, each at critical stages in development, are particularly sensitive to stressors that could have short- and long-term effects. Yet, few epidemiological studies have investigated the influence of early-life As exposure on immunological outcomes in children and even fewer in newborns and infants. Evidence indicates that early-life As exposure may have consequences that manifest much later in adulthood $[18,63]$, as evidenced by increased prevalence of and mortality from bronchiectasis and lung cancer in young adults [43]. Therefore, biomarkers indicative of future disease following early-life exposure could be evident in young subjects.

\section{Induction of apoptosis}

Indeed, studies of early-life As exposure have detected markers of immune dysfunction in infants and children. Studies of Mexican children aged 4-13 have reported higher incidences of apoptotic PBMC in As-exposed children relative to controls $[64,65]$. Although apoptosis is important in immune homeostasis, abnormal immune cell apoptosis can contribute to dysregulated immune function, which may result in immunodeficiency, autoimmune disease or malignant transformation [66]; thus, induced apoptosis may be important in As-mediated immunosuppression. The larger study of 40 children (high and low mean urinary As levels $=46.3$ and $14.2 \mu \mathrm{g} / \mathrm{g}$ creatinine, respectively) found a significant positive association between As exposure and apoptotic PBMC [65]. However, despite elevated apoptotic PBMC in chronicallyexposed children from the smaller study of 7 highlyexposed and 5 non-exposed children (mean urinary As levels $=143.9$ and $24.8 \mu \mathrm{g} / \mathrm{g}$ creatinine, respectively), no significant correlation was observed between exposure and apoptotic cells [64], in agreement with a study on adults [30], possibly due to small sample size or individual differences in As susceptibility [64].

\section{Lymphocyte activation}

Consistent with findings from adults [24-26], significant reductions in PBMC IL-2 secretion and proliferation were observed in As-exposed children aged 6-10 $(n=$ 90, mean urinary As levels of high- and low-exposure group $=194.9$ and $29.3 \mu \mathrm{g} / \mathrm{L}$, respectively) [67]. Also noteworthy were increased granulocyte-macrophage colony stimulating factor (GM-CSF) secretion and reduced $\mathrm{CD}^{+}{ }^{+}$cell count and $\mathrm{CD} 4 / \mathrm{CD} 8$ ratio without altered $\mathrm{CD}^{+}$cell proportion [67]. Because low CD4/CD8 is considered a surrogate marker of immunosuppression [68-70], the observed decrease in CD4/CD8 may be an early indicator of As-mediated immunosuppression. Furthermore, the increased GM-CSF secretion may indicate chronic inflammation given growing evidence of elevated GM-CSF levels in initiating/mediating chronic inflammation [71], and is consistent with a previous study of As-exposed adults demonstrating up-regulated inflammatory molecules [21].

\section{ROS production}

Production of the reactive oxygen species (ROS) $\mathrm{NO}^{-}$ and superoxide anion $\left(\mathrm{O}_{2}^{-}\right)$by activated PBMC is an important innate immune response to destroy invading microbes. Cross-sectional studies assessing As influence on ROS production in children have yielded conflicting results. Analysis of 87 children in Mexico ingesting Ascontaminated water showed that exposure positively associated with $\mathrm{O}_{2}^{-}$production by mitogen-stimulated monocytes and basal $\mathrm{NO}^{-}$and $\mathrm{O}_{2}^{-}$levels in PBMC and monocytes [72]. This is inconsistent with an earlier study of 65 children living near a primary smelter in Mexico in which As exposure was negatively associated with $\mathrm{NO}^{-}$and $\mathrm{O}_{2}^{-}$production by stimulated monocytes [73]. The discrepancy may be due to differences in exposure; children in the earlier study had lower urinary As levels (range 16.7-465.7 $\mu \mathrm{g} / \mathrm{g}$ creatinine) [73] than those in the more recent study (range 12.3-1411 $\mu \mathrm{g} / \mathrm{g}$ creatinine) [72]. Regardless of the source of variation in results, these studies suggest that As could alter circulating cells' ability to respond to immunological challenge. For example, elevated ROS levels in un-stimulated PBMC indicate Asinduced oxidative stress, concurrent with findings from copper smelter workers [27]; ROS overproduction by activated PBMC could cause oxidative damage to surrounding tissues, whereas diminished ROS production could weaken PBMC defense against pathogens.

\section{Prenatal exposure}

Because As readily crosses the placenta [74], it could potentially alter prenatal development. Indeed, gestational 
As exposure is linked to increased fetal loss and infant mortality $[75,76]$. However, reports on immune-related effects of prenatal exposure in newborns and infants are scarce. In a mother-child cohort study in Bangladesh $(n=140)$, maternal urinary As levels were significantly negatively correlated with child thymic index and breast milk trophic factors IL-7 (needed for thymic and T-cell development) and lactoferrin (an antioxidant and factor in innate immunity), and positively correlated with maternal morbidity and male infant RTI [77]. These findings are supported by a more recent prospective population-based cohort study of 1,552 infants born in Bangladesh, which revealed dose-dependent increases of $69 \%$ and $20 \%$ in infant lower RTI and diarrhea, respectively, related to exposure during pregnancy (maternal urinary As levels, lowest quintile $<39 \mu \mathrm{g} / \mathrm{L}$; highest quintile $=$ 262-977 $\mu \mathrm{g} / \mathrm{L}$ ) [78]. The observed increased prevalence of infant respiratory illness is consistent with As-associated adult non-malignant lung disease $[35,42]$ and marked increased risk of such disease following early-life exposures [43]. Moreover, enhanced male infant susceptibility to RTI is consistent with increased As-related pulmonary effects in men and not in women [36].

Another study of women delivering babies in Bangladesh $(n=130)$ found that gestational As exposure induced placental inflammation (IL- $1 \beta$, TNF- $\alpha$ and IFN- $\gamma$ ) via oxidative stress (8-oxoguanine), reduced placental $\mathrm{CD}^{+} \mathrm{T}$-cell numbers, and increased umbilical cord blood IL- 8 , IL- $1 \beta$, TNF- $\alpha$ and IFN- $\gamma$ [79]. These findings concur with reports of elevated oxidative stress [27] and inflammation [21] in chronically-exposed adults. In a follow-up study $(n=44)$, As levels in maternal urine and placental and cord blood positively associated with cord blood 8-hydroxy2'-deoxyguanosine and inversely associated with infant thymic function at birth, as measured by signal-joint Tcell receptor-rearrangement excision circles in cord blood mononuclear cells (CBMC) [80]. Further, prenatal As exposure was associated with down-regulated oxidativestress defense genes, including $S O D 3$, and up-regulated apoptosis-related genes in CBMC, including CASP2 [80], the latter consistent with results from adults [22].

Overall, these data indicate that in utero As exposure reduces infant thymic size and function, likely through inhibiting breast milk trophic factors and/or inducing apoptosis and oxidative stress. These effects may contribute to infant immune deficiency evidenced by increased RTI prevalence. Lack of data supporting a relationship between early-life As exposure and nonpulmonary infections suggests that the developing lung is specifically targeted by As. Furthermore, given increasing evidence of As-associated adverse immunerelated outcomes, it is likely that immune disruption resulting from early-life As exposure will have long-term detrimental consequences well into adulthood, as seen in increased prevalence of bronchiectasis and lung, kidney and bladder cancers.

\section{Experimental animal studies Gene expression}

In various animal models, As exposure is associated with altered expression of genes involved in immune response. In lungs of mice exposed to $\mathrm{As}^{\mathrm{III}}$ (< $100 \mathrm{ppb}$ ) for 56 weeks, significant changes were identified in transcripts encoding humoral immune response, antigen binding, TLRs, cytokines, cytokine receptors and genes involved in cell adhesion and migration [81,82]. Specifically, down-regulated expression of genes encoding TLR/IL1R signaling pathway, including $I l 1 b$, was identified [82]. In zebrafish embryos, As significantly inhibited induction of genes involved in regulating innate immune responses against viral and bacterial infection, including $i l 1 b$ [83], tnfa, ifnphi1 (type1 interferon) and $m x$ (interferon-inducible $\mathrm{Mx}$ ) [84,85]. As also disrupted JAK/ STAT pathway, which is critical in cytokine regulation [84]. These effects concur with epidemiological findings of As-associated decreased expression of $\operatorname{IL} 1 B[19,20]$ and TNF [22].

\section{Lymphocyte subpopulations}

Studies in rats [86-88], mice [89], catfish [90] and chickens [91] show that As can suppress the weight, index and/or cellularity of major immunocompetent organs, including spleen and thymus. In chronically-exposed mice, reduced $\mathrm{CD}_{4}{ }^{+} \mathrm{T}$-cell populations and $\mathrm{CD} 4 / \mathrm{CD} 8$ ratio were evident, concurrent with observations in Asexposed children [67], as well as increased percentage of monocytes in splenic mononuclear cells (SMC) [92]. In catfish, As increased atypical lymphocytes and depleted lymphoid and melano-macrophage populations in head kidney (HK), a major immunocompetent organ [90,93]. Interestingly, a single intra-tracheal exposure of mice to $200 \mathrm{mg} / \mathrm{kg}$ gallium arsenide (GaAs) markedly decreased peritoneal lymphocyte counts [94] and splenic T-cell, B-cell and macrophage numbers by 58, 61 and 30\%, respectively, without affecting their proportions [89].

\section{Lymphocyte activation}

Consistent with epidemiological observations [24-26,67], chronic As exposure inhibits mitogen-stimulated proliferation of PBMC and SMC in broiler chickens [91] and SMC in mice [92], and T-cell and B-cell proliferation in catfish spleen and HK $[90,93]$. Consequently, decreases have been observed in secretion of IFN- $\gamma$, IL-2, IL- 6 and IL-12 in mice [92], and "IL-4-like factors" from HK T-cells in catfish [93]. An important consideration regarding animal studies is that As concentrations administered typically far exceed human exposures, which may account for differential effects observed. 


\section{Humoral and hypersensitivity responses}

As can inhibit humoral immunity, as evidenced by suppressed in vitro primary and/or secondary antibodyforming cell (AFC) responses of rodent splenocytes [87,89,94-97]. IL-2 is a primary target of this inhibition in mice [98]. Further, As suppressed delayed-type hypersensitivity reaction, a response to cutaneous sensitization, in mice [94,99], rats [88,100] and chickens [91]. Compared to controls, $\mathrm{As}^{\mathrm{III}}$-exposed sensitized mice demonstrated reduced lymph node cell proliferation, ear swelling, activated Langerhans cells (LC) in cervical lymph nodes, peritoneal macrophages and circulating neutrophils [99], suggesting that As inhibits LC migration to lymph nodes and subsequent $\mathrm{T}$-cell activation.

\section{Macrophages}

Similar to humans [29], As exposure in animals suppresses macrophage production of $\mathrm{NO}^{-}$and/or $\mathrm{O}_{2}^{-}$[91,101-103], release of TNF- $\alpha$ [104], and phagocytosis [90,102,103]. In chronically-exposed animals, such effects may be longterm. Exposure of freshwater bivalve L. marginalis to As ${ }^{\text {III }}$ (1-5 ppm) for $<30$ days resulted in time- and dosedependent decreases in phagocytic efficiency and $\mathrm{NO}^{-}$ production in haemocytes, the major phagocytes and immune-effector cells in bivalves [102]. In a recovery assay, animals were maintained in As-free water for the same duration as exposure to evaluate immune efficiency. They demonstrated partial recovery of phagocytic potential, but inhibitory effects were still apparent; whereas $\mathrm{NO}^{-}$ production was restored to control levels in animals exposed to 1 ppm $\mathrm{As}^{\mathrm{III}}$ for $<4$ days, $\mathrm{NO}^{-}$generation remained suppressed in high-dose- and long-term-exposed animals [102]. As can also induce apoptosis in macrophages, as seen in 3-fold increased DNA fragmentation in splenic macrophages from $\mathrm{As}^{\mathrm{III}}$-exposed mice [103]. Further, splenic macrophages from As-treated mice demonstrated reduced adhesion and chemotactic index [105], surface I-A ${ }^{\mathrm{k}}(\mathrm{MHC})$ class II molecule expression and antigen presentation to T-cells [106]. Similar observations have been made in humans $[19,29]$, thus giving these results biological plausibility.

\section{Immune surveillance}

Altogether, these data indicate that in vivo As exposure can disrupt innate and humoral immunity. Studies of As influence on allogeneic immune response, i.e. rejection of MHC-mismatched allografts, suggest As disrupts the immune system's ability to distinguish "self" from "non-self" [107,108]. In a mouse heart transplantation model, arsenic trioxide $\left(\mathrm{As}_{2} \mathrm{O}_{3}\right)$ significantly reduced allograft rejection relative to control [107]. Similarly, $\mathrm{As}_{2} \mathrm{O}_{3}$ radically reduced severe symptoms of graft-versus-host disease in mice following allogeneic hematopoietic stem cell transplantation
[108]. Together with reported decreased macrophage I- $\mathrm{A}^{\mathrm{k}}$ class II expression and antigen presentation [106], these findings provide potential mechanisms whereby As can suppress the immune system's ability to discriminate self from non-self antigens.

Investigation of As influence on immune system regulation revealed redistributed nTreg lymphocytes following 3-week $\mathrm{As}^{\mathrm{III}}$ exposure in a rat model of multiple sclerosis, an autoimmune disease characterized by decreased nTreg cell number and function [30]. Whereas low As ${ }^{\mathrm{III}}$ doses increased nTreg cell number in spleen and alleviated severity of the autoimmune condition, concentrations $>100 \mu \mathrm{g} / \mathrm{L}$ reduced cell numbers in blood and spleen, consistent with epidemiological findings from that study [30]. Evidently, lowdose As-mediated increased number of splenic nTreg lymphocytes inhibited generation of (auto-) immune responses, hence the beneficial effect of immunosuppression by low-dose As. Thus, two possible scenarios whereby As can interfere with self/non-self recognition exist: by i) preventing immune surveillance from recognizing "non-self" from "self", leading to increased non-self antigen survival, as in allograft transplantation; or ii) inhibiting recognition of self antigens as "self", which could arise from As-induced reduction of nTreg cell inhibitory activity, leading to "anti-self" antibody production indicative of autoimmune disease. Such effects would likely render the host immunocompromised and could have detrimental health consequences.

Several models indicate that As compromises the immune system's ability to rid the host of pathogens and tumors. As-exposed mice demonstrating depressed humoral and cellular immunity displayed significantly impaired resistance against B16F10 melanoma, which resulted in 7-fold increased tumor burden [94]. $\mathrm{As}^{\mathrm{III}}$-exposed zebrafish embryos and larvae exhibited significant 57- to 80-fold increased viral titers and 17- to 19-fold increased bacterial loads [85], and decreased ROS production $[84,85]$. Exposure-challenge studies in catfish revealed efficient pathogen colonization in distant tissues [93] and increased ulcer and septicemia susceptibility following A. hydrophilia infection [90]. Investigations in mice yield conflicting results on As influence on clearance of infection. Whereas As delayed splenic clearance of S. aureus in one study [105], in another As apparently enhanced resistance to G. muris gastrointestinal infection [109]. While reasons for these inconsistencies are unclear, it should be noted that As inhibited splenic macrophage adhesion and chemotaxis by $>50 \%$ in the earlier study [105], which could explain increased bacterial survival. However, the later study did not examine other immune functional parameters [109]; thus, it stands to reason that As concentrations used were insufficient to achieve immunosuppressive effects. 
Table 1 Major findings of As-associated immune-related effects that are consistent across multiple studies

\begin{tabular}{|c|c|c|c|c|}
\hline $\begin{array}{l}\text { Immune } \\
\text { parameter }\end{array}$ & Major findings & Study model & Description & References \\
\hline \multirow{15}{*}{$\begin{array}{l}\text { Defense genes/ } \\
\text { proteins }\end{array}$} & $\downarrow$ MHC class $\|$ & Humans & PBMC mRNA & [19] \\
\hline & & Animals & Mouse macrophage surface expression & {$[106]$} \\
\hline & $\downarrow$ CD69 & Humans & PBMC mRNA & [19] \\
\hline & & Human cells & PBMC surface expression & [122] \\
\hline & & Animal cells & Mouse SMC surface expression & {$[115]$} \\
\hline & $\downarrow \| L-1 \beta$ & Humans & PBMC mRNA & {$[19,20]$} \\
\hline & & Animals & Mouse lung mRNA \& protein & {$[82,110]$} \\
\hline & & & Zebrafish mRNA & [83] \\
\hline & $\uparrow \mathrm{CD} 14$ & Humans & PBMC mRNA \& surface expression & {$[21,30]$} \\
\hline & & Human cells & Macrophage surface expression & {$[130,131]$} \\
\hline & $\downarrow$ TNF-a & Humans & PBMC mRNA & {$[20,22]$} \\
\hline & & & PBMC secretion & [26] \\
\hline & & Animals & Zebrafish mRNA & [84] \\
\hline & & & Rat PAM secretion & [104] \\
\hline & & & Mouse lung fluid protein & [110] \\
\hline \multirow[t]{5}{*}{ Inflammation } & $\begin{array}{l}\uparrow \text { Expression of } \\
\text { inflammatory } \\
\text { mediators }\end{array}$ & Humans & $\uparrow$ PBMC IL1B, IL6, CCL2 \& CD14 mRNA in adults & {$[21]$} \\
\hline & & & $\uparrow$ PBMC CD14 surface expression \& TNF-a secretion in adults & [30] \\
\hline & & & $\uparrow$ PBMC GM-CSF secretion in children & {$[67]$} \\
\hline & & & $\uparrow$ Placental \& cord blood IL-1 $\beta$, TNF- $a$ and IFN- $\gamma$ in neonates & [79] \\
\hline & & Human cells & $\uparrow$ Macrophage mRNA \& secretion of TNF-a \& IL-8 & [130] \\
\hline \multirow[t]{16}{*}{$\begin{array}{l}\text { Lymphocyte } \\
\text { activation }\end{array}$} & $\begin{array}{l}\downarrow \text { Stimulated } \\
\text { proliferation }\end{array}$ & Humans & PBMC in adults & {$[24-26]$} \\
\hline & & & PBMC in children & {$[67]$} \\
\hline & & Animals & Chicken SMC \& PBMC & [91] \\
\hline & & & Mouse SMC & [92] \\
\hline & & & Catfish SMC & {$[90,93]$} \\
\hline & & Human cells & PBMC & {$[113,114]$} \\
\hline & & Animal cells & Mouse SMC & {$[115,116]$} \\
\hline & & & Chicken SMC & [117] \\
\hline & $\begin{array}{l}\downarrow \text { Stimulated IL-2 } \\
\text { secretion }\end{array}$ & Humans & PBMC in adults & [26] \\
\hline & & & PBMC in children & {$[67]$} \\
\hline & & Animals & Mouse SMC & {$[92,98]$} \\
\hline & & & Catfish SMC & [93] \\
\hline & & Human cells & PBMC & {$[113,114]$} \\
\hline & & Animal cells & Mouse SMC & {$[115,116]$} \\
\hline & & & Chicken SMC & {$[117]$} \\
\hline & & & Harbor seal 11B7501 lymphoma B-cells & [118] \\
\hline \multirow[t]{2}{*}{$\begin{array}{l}\text { Humoral } \\
\text { immunity }\end{array}$} & $\begin{array}{l}\downarrow \text { AFC response to } \\
\text { antigen }\end{array}$ & Animals & $\begin{array}{l}\text { Mouse SMC } \\
\text { Rat SMC }\end{array}$ & $\begin{array}{l}{[89,94-96]} \\
{[87,97]}\end{array}$ \\
\hline & & Animal cells & Mouse SMC & {$[128,129]$} \\
\hline
\end{tabular}


Table 1 Major findings of As-associated immune-related effects that are consistent across multiple studies (Continued)

\begin{tabular}{|c|c|c|c|c|}
\hline $\begin{array}{l}\text { Immune } \\
\text { parameter }\end{array}$ & Major findings & Study model & Description & References \\
\hline \multirow[t]{2}{*}{$\begin{array}{l}\text { Hypersensitivity } \\
\text { reaction }\end{array}$} & \multirow{2}{*}{$\begin{array}{l}\downarrow \text { Response to } \\
\text { cutaneous } \\
\text { sensitization }\end{array}$} & \multirow[t]{2}{*}{ Animals } & $\begin{array}{l}\downarrow L C \text { migration to lymph nodes \& subsequent T-cell activation in mice } \\
\text { Rats }\end{array}$ & $\begin{array}{l}{[94,99]} \\
{[88,100]}\end{array}$ \\
\hline & & & Chickens & [91] \\
\hline \multirow{14}{*}{$\begin{array}{l}\text { Monocytes/ } \\
\text { macrophages }\end{array}$} & \multirow[t]{5}{*}{$\downarrow$ Number/survival } & Humans & $\downarrow$ Monocyte count & [28] \\
\hline & & \multirow[t]{3}{*}{ Animals } & $\downarrow$ Mouse splenic macrophage count & [89] \\
\hline & & & $\downarrow$ Catfish HK macrophage count & {$[90,93]$} \\
\hline & & & $\uparrow$ Apoptosis of mouse splenic macrophages & [103] \\
\hline & & Human cells & $\uparrow$ Apoptosis of blood monocytes \& U937 promonocytic cells & [126] \\
\hline & \multirow[t]{2}{*}{$\begin{array}{l}\text { Impaired } \\
\text { development }\end{array}$} & \multirow[t]{2}{*}{ Human cells } & $\downarrow$ Differentiation of monocytes into macrophages & [130-133] \\
\hline & & & Induced differentiation of macrophages into DC-like cells & {$[130,131]$} \\
\hline & \multirow[t]{7}{*}{$\begin{array}{l}\text { Diminished } \\
\text { function }\end{array}$} & Humans & $\begin{array}{l}\text { Cell rounding; } \downarrow \text { adhesion/CD54 adhesion molecule, F-actin, NO- } \\
\text { production \& phagocytosis; altered Rho A-ROCK signaling }\end{array}$ & [29] \\
\hline & & \multirow[t]{5}{*}{ Animals } & $\downarrow$ Rat PAM stimulated TNF-a secretion & [104] \\
\hline & & & $\downarrow$ Mouse peritoneal macrophage $\mathrm{NO}^{-} \& \mathrm{O}_{2}^{-}$production & [101] \\
\hline & & & $\begin{array}{l}\downarrow \text { Mouse splenic macrophage adhesion, chemotactic index, phagocytosis, } \\
\text { NO }^{-} \text {production, MHC class } \| \text { surface expression \& antigen presentation }\end{array}$ & {$[103,105,106]$} \\
\hline & & & $\downarrow$ Chicken SMC \& PBMC NO` production & [91] \\
\hline & & & $\downarrow$ Molluscan haemocyte phagocytosis \& $\mathrm{NO}^{-}$production & [102] \\
\hline & & Human cells & $\begin{array}{l}\text { Cell rounding; } \downarrow \text { adhesion \& macrophage-specific markers; reorganized F- } \\
\text { actin cytoskeleton resembling that of monocytes; } \uparrow \text { monocytic marker } \\
\text { CD14; } \downarrow \text { endocytosis \& phagocytosis via activated Rho A-ROCK signaling }\end{array}$ & {$[130,131]$} \\
\hline \multirow[t]{10}{*}{ Survival } & \multirow[t]{10}{*}{$\begin{array}{l}\uparrow \text { Induction of } \\
\text { apoptosis }\end{array}$} & \multirow[t]{4}{*}{ Humans } & PBMC in adults & {$[30]$} \\
\hline & & & $\uparrow$ PBMC BCL2L1 \& CASP2 mRNA in adults & [22] \\
\hline & & & PBMC in children & {$[64,65]$} \\
\hline & & & $\uparrow$ CBMC CASP2 mRNA in neonates & [80] \\
\hline & & Animals & Mouse splenic macrophages & [103] \\
\hline & & \multirow[t]{3}{*}{ Human cells } & Blood monocytes \& U937 promonocytic cells & {$[126]$} \\
\hline & & & PBMC & [64] \\
\hline & & & B-cells, T-cells, macrophages \& neutrophils & {$[123]$} \\
\hline & & \multirow[t]{2}{*}{ Animal cells } & Mouse TA3 antigen-presenting B-cells & {$[125]$} \\
\hline & & & Rat T-cells & [124] \\
\hline \multirow[t]{11}{*}{ ROS production } & \multirow[t]{4}{*}{$\begin{array}{l}\text { Induced oxidative } \\
\text { stress }\end{array}$} & \multirow[t]{4}{*}{ Humans } & $\uparrow$ Serum SOD \& PBMC MDA in adults & [27] \\
\hline & & & $\uparrow$ Basal PBMC/monocyte $\mathrm{NO}^{-} \& \mathrm{O}_{2}^{-}$in children & [72] \\
\hline & & & $\uparrow$ Placental 8-oxoguanine in neonates & [79] \\
\hline & & & $\uparrow$ Cord blood 8-hydroxy-2'-deoxyguanosine in neonates & {$[80]$} \\
\hline & \multirow[t]{7}{*}{$\begin{array}{l}\downarrow \text { Stimulated ROS } \\
\text { production }\end{array}$} & \multirow[t]{2}{*}{ Humans } & $\downarrow$ Macrophage $\mathrm{NO}^{-}$in adults & [29] \\
\hline & & & $\downarrow$ Monocyte $\mathrm{NO}^{-} \& \mathrm{O}_{2}^{-}$in children & [73] \\
\hline & & \multirow[t]{5}{*}{ Animals } & $\downarrow$ Mouse peritoneal macrophage $\mathrm{NO}^{-} \& \mathrm{O}_{2}^{-}$ & [101] \\
\hline & & & $\downarrow$ Mouse splenic macrophage $\mathrm{NO}^{-}$ & {$[103,105,106]$} \\
\hline & & & $\downarrow$ Chicken SMC \& PBMC NO- & [91] \\
\hline & & & $\downarrow$ Molluscan haemocyte $\mathrm{NO}^{-}$ & [102] \\
\hline & & & Zebrafish embryos \& larvae & {$[84,85]$} \\
\hline
\end{tabular}


Table 1 Major findings of As-associated immune-related effects that are consistent across multiple studies (Continued)

\begin{tabular}{|c|c|c|c|c|}
\hline $\begin{array}{l}\text { Immune } \\
\text { parameter }\end{array}$ & Major findings & Study model & Description & References \\
\hline \multirow[t]{4}{*}{$\begin{array}{l}\text { Microbial } \\
\text { challenge }\end{array}$} & $\begin{array}{l}\downarrow \text { Clearance of } \\
\text { pathogens }\end{array}$ & Animals & $\uparrow$ Viral \& bacterial loads in zebrafish embryos and larvae & [85] \\
\hline & & & $\begin{array}{l}\uparrow \text { Pathogen colonization \& ulcers/septicemia following bacterial infection } \\
\text { in catfish }\end{array}$ & {$[90,93]$} \\
\hline & & & $\downarrow$ Splenic clearance of S. aureus in mice & [105] \\
\hline & & & $\uparrow$ Morbidity \& respiratory viral titers following $\mathrm{H} 1 \mathrm{~N} 1$ viral infection in mice & [110] \\
\hline \multirow[t]{12}{*}{$\begin{array}{l}\text { Pulmonary } \\
\text { health }\end{array}$} & $\begin{array}{l}\text { Altered lung } \\
\text { features }\end{array}$ & Humans & Altered airway protein expression in adults & {$[139,141]$} \\
\hline & & Animals & Altered mouse airway protein expression & {$[140,141]$} \\
\hline & & & $\downarrow$ Rat PAM stimulated TNF-a secretion & [104] \\
\hline & & & $\downarrow$ Mouse lung expression of genes involved in cell adhesion/migration & {$[81,82]$} \\
\hline & & & $\downarrow$ Killifish gill chloride secretion via $\uparrow$ CFTR degradation & [136] \\
\hline & & Human cells & $\downarrow$ CFBE41o- AE cell chloride secretion via $\uparrow$ CFTR degradation & [135] \\
\hline & & & $\downarrow 16 \mathrm{HBE} 14 \mathrm{O}-$ bronchial epithelial cell migration and wound repair & {$[137,138]$} \\
\hline & & Animal cells & $\downarrow$ Rat PAM stimulated TNF-a secretion \& $\mathrm{NO}^{-} \& \mathrm{O}_{2}^{-}$production & [104] \\
\hline & $\begin{array}{l}\uparrow \text { Risk of infection/ } \\
\text { disease }\end{array}$ & Humans & $\uparrow$ RTI \& tuberculosis in adults & {$[26,29,35]$} \\
\hline & & & $\begin{array}{l}\downarrow \text { Lung function; } \uparrow \text { prevalence/mortality from lung cancer and non- } \\
\text { malignant lung disease, including bronchitis \& bronchiectasis in adults }\end{array}$ & {$[34,36-41]$} \\
\hline & & & $\uparrow R T I$ in infants & {$[77,78]$} \\
\hline & & Animals & $\uparrow$ Morbidity \& respiratory viral titers following $\mathrm{H} 1 \mathrm{~N} 1$ infection in mice & {$[110]$} \\
\hline
\end{tabular}

Note: all cells are primary cells unless otherwise stated. Subjects of human studies are adults unless otherwise stated.

$\downarrow$ decreased; $\uparrow$ increased.

Chronic low-dose $\mathrm{As}^{\mathrm{III}}(<100 \mathrm{ppb})$ exposure of mice aggravated H1N1 influenza A infection severity, increasing morbidity and respiratory viral titers [110]. Early in the infection, As suppressed lymphocyte, macrophage and neutrophil migration to lungs and dendritic cell (DC) recruitment to lymph nodes, and inhibited production of $9 / 10$ cytokines, including TNF- $\alpha$ and IL-1 $\beta$ [110], concurrent with downregulated cytokines and adhesion- and migrationrelated genes in lungs of uninfected As-exposed mice $[81,82]$. As depressed DC migration in in vitro assays of bone marrow-derived DC from uninfected Asexposed relative to unexposed mice [110]. Similarly, $\mathrm{As}_{2} \mathrm{O}_{3}$ reduced DC density, T helper 17 (Th17) cells, which play a major role in defense against infections, and levels of the major pro-inflammatory cytokine IL17 in airways of asthmatic mice [111,112]. Although cell counts and cytokine levels in lungs of As-exposed mice were similar to or higher than those of controls by day 7 post-infection [110], these results show that prolonged As exposure can impair immune responses against infection, and suggest that impaired response to repeated infections could promote chronic human diseases such as bronchiectasis.

\section{In vitro studies}

\section{Lymphocyte activation}

In vitro As exposure suppressed IL-2 secretion and proliferation of mitogen-stimulated lymphocytes from humans and various animal species [113-118]. A biphasic dose-dependent response was observed following $\mathrm{As}^{\mathrm{III}}$ or $\mathrm{As}^{\mathrm{V}}$ exposure of mitogen-stimulated human and bovine PBMC [119], demonstrating As immunosuppressive effects depend on the dose. As markedly suppressed lymphocyte secretion and/or mRNA levels of IFN- $\gamma$, IL-4 and IL-10 in different in vitro models $[114,116,117]$. As ${ }^{\mathrm{III}}$ also significantly impaired differentiation of human Th17 cells by repressing their expression and release of IL-17 and decreasing expression of ROR $\gamma \mathrm{t}$, which regulates IL17, through inactivation of JNK/C-Jun pathway [120]. $\mathrm{As}^{\mathrm{III}}$ further impaired Th17 cells by disrupting functions of DC, which regulate Th17 cell differentiation, via i) blocking DC differentiation through induced necrosis; ii) decreasing DC endocytotic activity; iii) repressing secretion of IL-12p70 and IL-23, two major regulators of Th17 activities, by activated DC; and iv) reducing ability of activated $\mathrm{DC}$ to stimulate IFN- $\gamma$ and IL-17 release from Th17 cells [121]. 
In contrast with reduced $\mathrm{CD} 4^{+}$and unaltered $\mathrm{CD} 8^{+} \mathrm{T}$-cell populations in children [67] and mice [92], in vitro As ${ }^{\text {III }}$ treatment of mitogen-stimulated mouse T-lymphocytes decreased $\mathrm{CD}^{+}$counts without affecting $\mathrm{CD} 4^{+}$counts [115]. Additionally, As ${ }^{\text {III }}$ inhibited early activation of mouse $\mathrm{CD}^{+}{ }^{+}$and $\mathrm{CD} 8^{+}$cells, as evidenced by reduced surface CD69 expression [115], an effect that was reported at the protein level in in vitro As-exposed human $\mathrm{CD}_{4}^{+}$and $\mathrm{CD}^{+}$lymphocytes [122] and also at the mRNA level in lymphocytes of As-exposed humans [19].

\section{Induction of apoptosis and humoral immunity}

As immunosuppressive effects are further demonstrated in vitro by increased apoptotic rates in B-cells, T-cells, macrophages and neutrophils [64,123-127]. Prior to inducing apoptosis in TA3 mouse antigen-presenting B-cells, As ${ }^{\mathrm{III}}$ inhibited activity of lysosomal protease cathepsin L, which is important in antigen processing/presentation to elicit T-cell responses [125]. This could possibly potentiate As-induced suppression of humoral immunity, for in vitro As exposure inhibits AFC responses of mouse splenocytes $[128,129]$, consistent with animal studies.

\section{Macrophages}

As exposure disrupts monocyte/macrophage survival, development and function in vitro. $\mathrm{As}_{2} \mathrm{O}_{3}$-exposed human blood monocytes and U937 promonocytic cells underwent marked apoptosis during macrophagic differentiation, an important event in immune response, likely through inhibition of NF-kB-related survival pathways [126]. Further, As inhibited differentiation of human monocytes into macrophages, reversed macrophagespecific features, and impaired endocytosis/phagocytosis, essentially leading to macrophagic "de-differentiation" [130-134]. Interestingly, $\mathrm{As}_{2} \mathrm{O}_{3}$ enhanced LPS-induced macrophage TNF- $\alpha$ and IL-8 mRNA and secretion [130], suggesting As toxicity toward macrophages is complex, and supporting epidemiological findings of As-associated inflammation [21]. Altogether, these data support epidemiological evidence of disrupted macrophage function [29] and impaired phagocytosis/antimicrobial responses by macrophages of As-exposed mice [105].

\section{Pulmonary effects}

Proposed mechanisms for As-associated compromised respiratory immunity include impaired pulmonary alveolar macrophage (PAM) function, demonstrated by markedly reduced LPS-stimulated TNF- $\alpha$ and $\mathrm{O}_{2}^{-}$production [104], and decreased airway epithelial (AE) chloride secretion cystic fibrosis transmembrane conductance regulator (CFTR), an essential chloride channel for mucociliary clearance of pathogens, as seen in human CFBE41o- AE cells [135] and killifish gills [136]. In human 16HBE14o- AE cells, As restricted wound response, i.e. monolayer reformation following scraping of cultures, through MMP9 up-regulation [137] and inhibition of paracrine $\mathrm{Ca}^{2+}$ signaling [138], consistent with downregulated adhesion- and migration-related genes in lungs of mice $[81,82]$ and altered airway proteins in mice and humans [139-141]. Collectively, these data suggest As disrupts pulmonary defense through mechanisms involving i) altered PAM function, ii) decreased AE chloride secretion resulting in depressed clearance of pathogens, and iii) $\mathrm{AE}$ remodeling due to impaired wound response, ultimately promoting chronic lung diseases such as bronchiectasis.

Table 2 Summary of specific observations of As-associated immune-related effects

\begin{tabular}{|c|c|c|}
\hline Major findings & Biological relevance & References \\
\hline $\begin{array}{l}\downarrow n \text { Treg lymphocyte number \& function in adults; redistribution } \\
\text { in rat model of autoimmune disease }\end{array}$ & $\begin{array}{l}\text { nTreg cells play critical role in immune homeostasis; alterations } \\
\text { could affect self-recognition or influence autoimmune disease }\end{array}$ & {$[30]$} \\
\hline Prenatal As exposure $\downarrow$ infant thymic size \& function & $\begin{array}{l}\text { Thymus is site of T-cell development; impaired function may } \\
\text { account for } \uparrow \text { prevalence of As-associated respiratory, cancer \& } \\
\text { other immune-related effects in adulthood }\end{array}$ & {$[77,80]$} \\
\hline$\downarrow$ CD4/CD8 T-cell ratio in children \& mice & Indicator of immune suppression & {$[67,92]$} \\
\hline $\begin{array}{l}\downarrow \text { Rejection of MHC mismatched heart/bone marrow allografts in } \\
\text { mice }\end{array}$ & $\begin{array}{l}\downarrow \text { Immune surveillance could lead to immunocompromised } \\
\text { state } \& \downarrow \text { ability to fight infection/cancer cells }\end{array}$ & {$[107,108]$} \\
\hline $\begin{array}{l}\downarrow \text { Resistance in mice against B16F10 melanoma resulted in 7-fold } \\
\uparrow \text { tumor burden }\end{array}$ & $\downarrow$ Anti-tumor immunity could lead to cancer development & {$[94]$} \\
\hline $\begin{array}{l}\downarrow \text { Migration of lymphocytes, macrophages \& neutrophils to } \\
\text { lungs/DC to lymph nodes early in course of H1N1 influenza } \\
\text { infection in mice }\end{array}$ & $\begin{array}{l}\downarrow \text { Immune surveillance could lead to immunocompromised } \\
\text { state } \& \downarrow \text { ability to fight infection/cancer cells }\end{array}$ & {$[110]$} \\
\hline $\begin{array}{l}\downarrow \text { DC density, IL-17 \& Th17 cells in asthmatic mouse airways; } \downarrow \\
\text { Th17 cell differentiation \& IL-17 release via disrupted JNKVC-Jun } \\
\text { pathway \& DC function }\end{array}$ & $\begin{array}{l}\text { Th17 cells play a major role in defense against infection via } \\
\text { release of major pro-inflammatory cytokine IL-17; disruption } \\
\text { could } \downarrow \text { ability to fight infection }\end{array}$ & {$[111,112,120,121]$} \\
\hline $\begin{array}{l}\downarrow \text { Urinary HBD1 peptides in men; } \downarrow \text { DEFB1 mRNA in human } 293 \mathrm{~T} \\
\text { renal and HeLa cervical cells }\end{array}$ & $\begin{array}{l}\text { HBD1 is antimicrobial peptide implicated in host anti-tumor \& } \\
\text { pulmonary immunity; its down-regulation could contribute to } \\
\text { As-induced cancers \& respiratory illnesses observed in humans }\end{array}$ & {$[50]$} \\
\hline
\end{tabular}

$\downarrow$ decreased; $\uparrow$ increased. 


\section{Discussion}

Studies reviewed here show that As significantly impacts both innate and adaptive immune defenses. Likely mechanisms involve altered expression of key immune regulators, induced apoptosis, oxidative stress and inflammation in circulating PBMC, impaired lymphocyte activation and macrophage function, and altered cellular and humoral immunity (Table 1). Specific examples of concordance between epidemiological and experimental data are i) reduced expression of MHC class II molecules, CD69, IL-1 $\beta$ and TNF- $\alpha$; ii) altered expression of airway adhesion- and migration-related genes/proteins; iii) decreased stimulated lymphocyte proliferation and IL-2 secretion; iv) impaired macrophage adhesion, phagocytosis and stimulated ROS production involving altered Rho A-ROCK signaling; v) induced apoptosis of PBMC; and vi) decreased stimulated ROS production by PBMC (Table 1). These effects can result in immunosuppression, as evidenced by reduced microbial clearance in animals and increased prevalence of opportunistic infections in humans, particularly RTI. Furthermore, epidemiological data suggest marked susceptibility of the lung to perturbation by As, especially during prenatal and childhood development, which results in unprecedented rates of chronic lung diseases, notably lung cancer and bronchiectasis. Experimental data suggest that such pulmonary effects could involve disrupted PAM function and airway remodeling resulting in impaired clearance of pulmonary pathogens. The pleiotropic effects of As on the immune system, including specific examples of compromised immune surveillance such as decreased rejection of MHC mismatched allografts and reduced migration of PBMC, neutrophils and DC to sites of infection in various animal models (Table 2), lend biological plausibility to increased rates of infection, cancers and other immune-related illnesses observed in As-exposed human populations, and are illustrated in Figure 1.

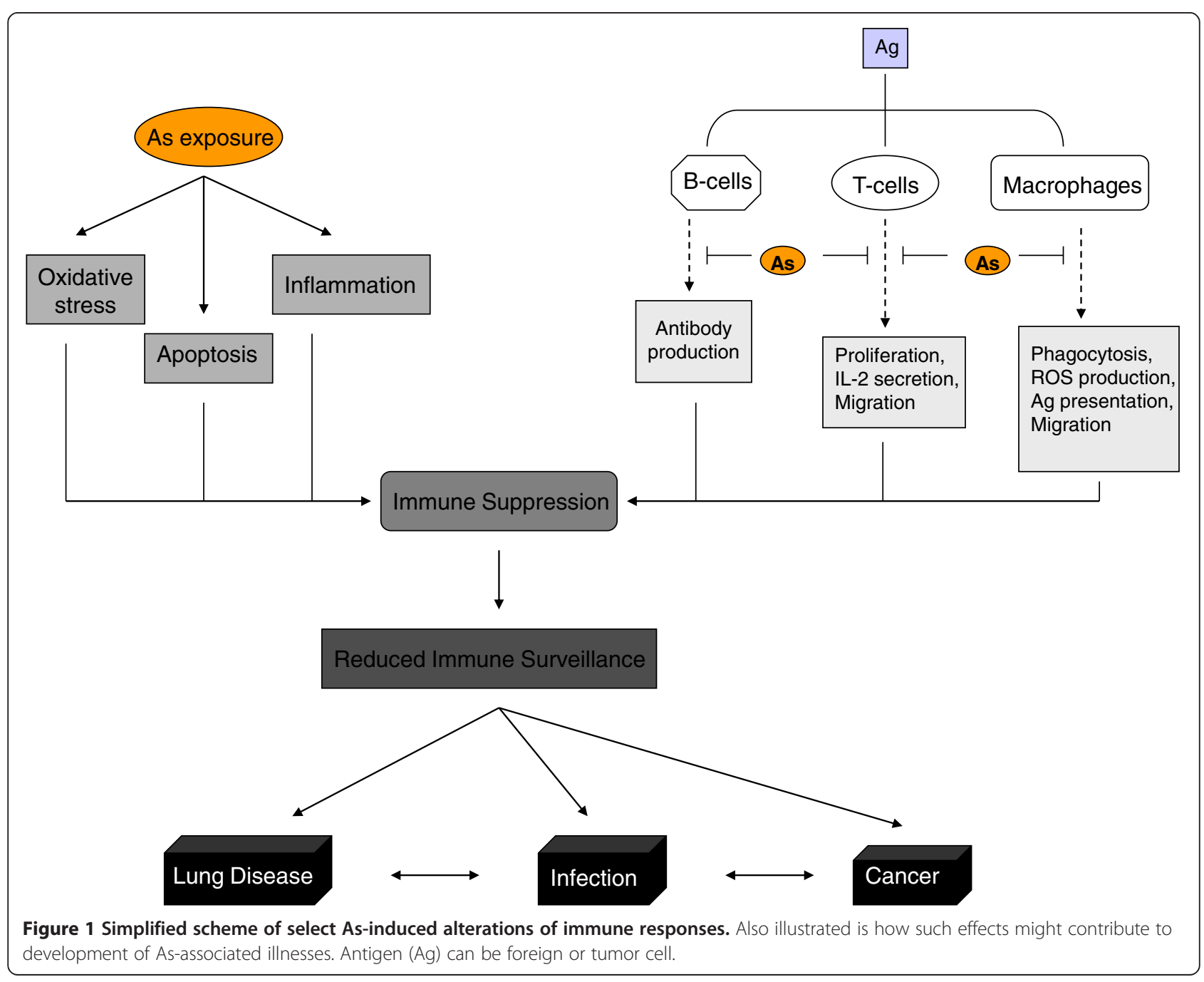




\section{Conclusions}

In vivo and in vitro studies depict As as an immunomodulator that could render the host immunocompromised. Such immune alterations could help explain increased risk of infections and several cancers observed in chronically-exposed human populations. As-mediated alterations of cellular and humoral immunity reported in animal and in vitro models generally agree with immunological outcomes in humans. However, more work is needed to close the gap between experimental data and risk of human immunotoxicity. Moreover, inconsistencies in epidemiological findings, possibly due to differences in dose, sampling, genetic background, and environmental/ nutritional factors, indicate need for larger participant numbers and diverse ethnic populations. Due to differential effects of exposures, populations having low, intermediate and high exposure should be evaluated to better understand dose-dependent relationships. Furthermore, strong evidence for an association between developmental As exposure and elevated risk of human disease necessitates more investigations of early-life exposure outcomes. Finally, comprehensive genomic, proteomic and metabolomic profiling will be critical for identifying and validating potential molecular targets of As to monitor progression of As-associated diseases and elucidate mechanisms of As immunotoxicity.

\begin{abstract}
Abbreviations
AE: Airway epithelial; AFC: Antibody-forming cell; As: Arsenic; As III: Arsenite; $\mathrm{As}^{\mathrm{V}}$ : Arsenate; $\mathrm{As}_{2} \mathrm{O}_{3}$ : Arsenic trioxide; CBMC: Cord blood mononuclear cells; CFTR: Cystic fibrosis transmembrane conductance regulator; DC: Dendritic cells; GaAs: Gallium arsenide; GM-CSF: Granulocyte-macrophage colony stimulating factor; HBD1: Human $\beta$-defensin-1; HK: Head kidney; LC: Langerhans cells; MDA: Malondialdehyde; nTreg: Natural T regulatory; $\mathrm{NO}^{-}$: Nitric oxide anion; $\mathrm{O}_{2}^{-}$: Superoxide anion; PAM: Pulmonary alveolar macrophages; PBMC: Peripheral blood mononuclear cells; ROS: Reactive oxygen species; RTI: Respiratory tract infections; SMC: Splenic mononuclear cells; SOD: Superoxide dismutase.
\end{abstract}

\section{Competing interests}

The authors declare that they have no competing interests.

\section{Authors' contributions}

NLD, CFS and MTS conceived of the study; NLD reviewed the literature and wrote and edited the manuscript; CFS and MTS critically reviewed the manuscript. All authors read and approved the final manuscript.

\section{Acknowledgments}

We thank Elizabeth Trenkwalder and Dr. Fenna Sillé for assistance with PubMed literature searches and final preparation of the manuscript for submission, respectively. This work was supported by the National Institute of Environmental Health Sciences [P42 ES004705 to MTS] and the National Science Foundation [NSF 04-615 to NLD].

\section{Author details}

'Division of Environmental Health Sciences, School of Public Health, University of California, Berkeley, CA 94720, USA. ${ }^{2}$ Department of Epidemiology, School of Public Health, University of Alabama, Birmingham, AL 35294, USA.

Received: 19 March 2013 Accepted: 24 August 2013

Published: 2 September 2013

\section{References}

1. IARC: A Review of Human Carcinogens: Arsenic, Metals, Fibres, and Dusts vol. 100C. Geneva, Switzerland: World Health Organization; 2012.

2. Liu J, Waalkes MP: Liver is a target of arsenic carcinogenesis. Toxico/ SC 2008, 105:24-32.

3. Hughes MF, Beck BD, Chen Y, Lewis AS, Thomas DJ: Arsenic exposure and toxicology: a historical perspective. Toxico/ Sci 2011, 123:305-332.

4. Nordstrom DK: Public health. Worldwide occurrences of arsenic in ground water. Science 2002, 296:2143-2145.

5. Drobna Z, Naranmandura H, Kubachka KM, Edwards BC, Herbin-Davis K, Styblo M, Le XC, Creed JT, Maeda N, Hughes MF, Thomas DJ: Disruption of the arsenic ( +3 oxidation state) methyltransferase gene in the mouse alters the phenotype for methylation of arsenic and affects distribution and retention of orally administered arsenate. Chem Res Toxicol 2009, 22:1713-1720.

6. Mass MJ, Tennant A, Roop BC, Cullen WR, Styblo M, Thomas DJ, Kligerman AD: Methylated trivalent arsenic species are genotoxic. Chem Res Toxicol 2001, 14:355-361.

7. Petrick JS, Ayala-Fierro F, Cullen WR, Carter DE, Vasken Aposhian $\mathrm{H}$ : Monomethylarsonous acid (MMA(III)) is more toxic than arsenite in Chang human hepatocytes. Toxicol Appl Pharmacol 2000, 163:203-207.

8. Petrick JS, Jagadish B, Mash EA, Aposhian HV: Monomethylarsonous acid (MMA(III)) and arsenite: $\mathrm{LD}(50)$ in hamsters and in vitro inhibition of pyruvate dehydrogenase. Chem Res Toxicol 2001, 14:651-656.

9. Styblo M, Del Razo LM, Vega L, Germolec DR, LeCluyse EL, Hamilton GA, Reed W, Wang C, Cullen WR, Thomas DJ: Comparative toxicity of trivalent and pentavalent inorganic and methylated arsenicals in rat and human cells. Arch Toxicol 2000, 74:289-299.

10. Chen YC, Guo YL, Su HJ, Hsueh YM, Smith TJ, Ryan LM, Lee MS, Chao SC, Lee JY, Christiani DC: Arsenic methylation and skin cancer risk in southwestern Taiwan. J Occup Environ Med 2003, 45:241-248.

11. Steinmaus C, Bates MN, Yuan Y, Kalman D, Atallah R, Rey OA, Biggs ML, Hopenhayn C, Moore LE, Hoang BK, Smith AH: Arsenic methylation and bladder cancer risk in case-control studies in Argentina and the United States. J Occup Environ Med 2006, 48:478-488.

12. Flora SJ: Arsenic-induced oxidative stress and its reversibility. Free Radic Biol Med 2011, 51:257-281.

13. IARC: Some drinking-water disinfectants and contaminants, including arsenic. In IARC Monogr Eval Carcinog Risks Hum, vol. 84. Geneva, Switzerland: World Health Organization; 2004:1-477.

14. NRC: Arsenic in Drinking Water: 2001 Update. Washington, D C: National Academy Press; 2001

15. Reichard JF, Schnekenburger M, Puga A: Long term low-dose arsenic exposure induces loss of DNA methylation. Biochem Biophys Res Commun 2007, 352:188-192.

16. Tokar EJ, Qu W, Waalkes MP: Arsenic, stem cells, and the developmental basis of adult cancer. Toxicol Sci 2011, 120(Suppl 1):S192-203.

17. Selgrade MK: Immunotoxicity: the risk is real. Toxicol Sci 2007, 100:328-332.

18. Vahter M: Health effects of early life exposure to arsenic. Basic Clin Pharmacol Toxicol 2008, 102:204-211.

19. Andrew AS, Jewell DA, Mason RA, Whitfield ML, Moore JH, Karagas MR Drinking-water arsenic exposure modulates gene expression in human lymphocytes from a U.S. population. Environ Health Perspect 2008, 116:524-531.

20. Argos M, Kibriya MG, Parvez F, Jasmine F, Rakibuz-Zaman M, Ahsan H: Gene expression profiles in peripheral lymphocytes by arsenic exposure and skin lesion status in a Bangladeshi population. Cancer Epidemiol Biomarkers Prev 2006, 15:1367-1375.

21. Wu MM, Chiou HY, Ho IC, Chen CJ, Lee TC: Gene expression of inflammatory molecules in circulating lymphocytes from arsenic-exposed human subjects. Environ Health Perspect 2003, 111:1429-1438.

22. Salgado-Bustamante M, Ortiz-Perez MD, Calderon-Aranda E, Estrada-Capetillo L, Nino-Moreno P, Gonzalez-Amaro R, Portales-Perez D: Pattern of expression of apoptosis and inflammatory genes in humans exposed to arsenic and/or fluoride. Sci Total Environ 2010, 408:760-767.

23. Tokar EJ, Qu W, Liu J, Liu W, Webber MM, Phang JM, Waalkes MP: Arsenic-specific stem cell selection during malignant transformation. J Natl Cancer Inst 2010, 102:638-649.

24. Ostrosky-Wegman P, Gonsebatt ME, Montero R, Vega L, Barba H, Espinosa J, Palao A, Cortinas C, Garcia-Vargas G, Del Razo LM, Cebrian M: Lymphocyte proliferation kinetics and genotoxic findings in a pilot study on 
individuals chronically exposed to arsenic in Mexico. Mutat Res 1991, 250:477-482.

25. Gonsebatt ME, Vega L, Montero R, Garcia-Vargas G, Del Razo LM, Albores A, Cebrian ME, Ostrosky-Wegman P: Lymphocyte replicating ability in individuals exposed to arsenic via drinking water. Mutat Res 1994, 313:293-299.

26. Biswas R, Ghosh P, Banerjee N, Das JK, Sau T, Banerjee A, Roy S, Ganguly S, Chatterjee M, Mukherjee A, Giri AK: Analysis of T-cell proliferation and cytokine secretion in the individuals exposed to arsenic. Hum Exp Toxicol 2008, 27:381-386.

27. Escobar J, Varela-Nallar L, Coddou C, Nelson P, Maisey K, Valdes D, Aspee A, Espinosa V, Rozas C, Montoya M, Mandiola C, Rodríguez FE, Acuña-Castillo C, Escobar A, Fernández R, Diaz H, Sandoval M, Imarai M, Rios M: Oxidative damage in lymphocytes of copper smelter workers correlated to higher levels of excreted arsenic. Mediators Inflamm 2010, 2010:403830.

28. Maiti S, Chattopadhyay S, Deb B, Samanta T, Maji G, Pan B, Ghosh A, Ghosh $D$ : Antioxidant and metabolic impairment result in DNA damage in arsenic-exposed individuals with severe dermatological manifestations in Eastern India. Environ Toxicol 2012, 27:342-350.

29. Banerjee N, Banerjee S, Sen R, Bandyopadhyay A, Sarma N, Majumder P, Das JK, Chatterjee M, Kabir SN, Giri AK: Chronic arsenic exposure impairs macrophage functions in the exposed individuals. J Clin Immunol 2009, 29:582-594.

30. Hernandez-Castro B, Doniz-Padilla LM, Salgado-Bustamante M, Rocha D, Ortiz-Perez MD, Jimenez-Capdeville ME, Portales-Perez DP, Quintanar-Stephano A, Gonzalez-Amaro R: Effect of arsenic on regulatory T cells. J Clin Immunol 2009, 29:461-469.

31. Miyara M, Sakaguchi S: Natural regulatory T cells: mechanisms of suppression. Trends Mol Med 2007, 13:108-116.

32. Ehrenstein MR, Evans JG, Singh A, Moore S, Warnes G, Isenberg DA, Mauri C: Compromised function of regulatory $\mathrm{T}$ cells in rheumatoid arthritis and reversal by anti-TNFalpha therapy. J Exp Med 2004, 200:277-285.

33. Bencko V, Wagner $\mathrm{V}$, Wagnerova M, Batora J: Immunological profiles in workers of a power plant burning coal rich in arsenic content. $J$ Hyg Epidemiol Microbiol Immunol 1988, 32:137-146.

34. Islam LN, Nabi AH, Rahman MM, Zahid MS: Association of respiratory complications and elevated serum immunoglobulins with drinking water arsenic toxicity in human. J Environ Sci Health A Tox Hazard Subst Environ Eng 2007, 42:1807-1814.

35. Smith AH, Marshall G, Yuan Y, Liaw J, Ferreccio C, Steinmaus C: Evidence from Chile that arsenic in drinking water may increase mortality from pulmonary tuberculosis. Am J Epidemiol 2011, 173:414-420.

36. Von Ehrenstein OS, Mazumder DN, Yuan Y, Samanta S, Balmes J, Sil A, Ghosh N, Hira-Smith M, Haque R, Purushothamam R, Lahiri S, Das S, Smith AH: Decrements in lung function related to arsenic in drinking water in West Bengal, India. Am J Epidemiol 2005, 162:533-541.

37. Tsai SM, Wang TN, Ko YC: Mortality for certain diseases in areas with high levels of arsenic in drinking water. Arch Environ Health 1999, 54:186-193.

38. De BK, Majumdar D, Sen S, Guru S, Kundu S: Pulmonary involvement in chronic arsenic poisoning from drinking contaminated ground-water. J Assoc Physicians India 2004, 52:395-400.

39. Mazumder DN, Haque R, Ghosh N, De BK, Santra A, Chakraborti D, Smith $\mathrm{AH}$ : Arsenic in drinking water and the prevalence of respiratory effects in West Bengal, India. Int J Epidemio/ 2000, 29:1047-1052.

40. Milton AH, Rahman M: Respiratory effects and arsenic contaminated well water in Bangladesh. Int J Environ Health Res 2002, 12:175-179.

41. Milton AH, Hasan Z, Rahman A, Rahman M: Non-cancer effects of chronic arsenicosis in Bangladesh: preliminary results. J Environ Sci Health A Tox Hazard Subst Environ Eng 2003, 38:301-305.

42. Mazumder DN, Steinmaus C, Bhattacharya P, Von Ehrenstein OS, Ghosh N, Gotway M, Sil A, Balmes JR, Haque R, Hira-Smith MM, Smith AH: Bronchiectasis in persons with skin lesions resulting from arsenic in drinking water. Epidemiology 2005, 16:760-765.

43. Smith AH, Marshall G, Yuan Y, Ferreccio C, Liaw J, Von Ehrenstein O, Steinmaus C, Bates MN, Selvin S: Increased mortality from lung cancer and bronchiectasis in young adults after exposure to arsenic in utero and in early childhood. Environ Health Perspect 2006, 114:1293-1296.

44. Ilowite J, Spiegler P, Chawla S: Bronchiectasis: new findings in the pathogenesis and treatment of this disease. Curr Opin Infect Dis 2008, 21:163-167.
45. King P, Holdsworth S, Freezer N, Holmes P: Bronchiectasis. Intern Med J 2006, 36:729-737.

46. Yuan Y, Marshall G, Ferreccio C, Steinmaus C, Liaw J, Bates M, Smith AH: Kidney cancer mortality: fifty-year latency patterns related to arsenic exposure. Epidemiology 2010, 21:103-108.

47. Marshall G, Ferreccio C, Yuan Y, Bates MN, Steinmaus C, Selvin S, Liaw J, Smith AH: Fifty-year study of lung and bladder cancer mortality in Chile related to arsenic in drinking water. J Natl Cancer Inst 2007, 99:920-928.

48. Rahman M, Vahter M, Sohel N, Yunus M, Wahed MA, Streatfield PK, Ekstrom EC, Persson LA: Arsenic exposure and age and sex-specific risk for skin lesions: a population-based case-referent study in Bangladesh. Environ Health Perspect 2006, 114:1847-1852.

49. Lindberg AL, Ekstrom EC, Nermell B, Rahman M, Lonnerdal B, Persson LA Vahter M: Gender and age differences in the metabolism of inorganic arsenic in a highly exposed population in Bangladesh. Environ Res 2008, 106:110-120.

50. Hegedus CM, Skibola CF, Warner M, Skibola DR, Alexander D, Lim S, Dangleben NL, Zhang L, Clark M, Pfeiffer RM, Steinmaus C, Smith AH, Smith MT, Moore LE: Decreased urinary beta-defensin-1 expression as a biomarker of response to arsenic. Toxicol Sci 2008, 106:74-82.

51. Goldman MJ, Anderson GM, Stolzenberg ED, Kari UP, Zasloff M, Wilson JM: Human beta-defensin-1 is a salt-sensitive antibiotic in lung that is inactivated in cystic fibrosis. Cell 1997, 88:553-560.

52. Weinberg A, Krisanaprakornkit S, Dale BA: Epithelial antimicrobial peptides: review and significance for oral applications. Crit Rev Oral Biol Med 1998, 9:399-414.

53. Moser C, Weiner DJ, Lysenko E, Bals R, Weiser JN, Wilson JM: beta-Defensin 1 contributes to pulmonary innate immunity in mice. Infect Immun 2002, 70:3068-3072

54. Ichikawa T, Nihei N, Kuramochi H, Kawana Y, Killary AM, Shimazaki J, Oshimura M, Kugoh H, Isaacs JT, Barrett JC, Rinker Schaeffer CW: Metastasis suppressor genes for prostate cancer. Prostate Supp/ 1996, 6:31-35.

55. Knuutila S, Aalto Y, Autio K, Bjorkqvist AM, El-Rifai W, Hemmer S, Huhta T, Kettunen E, Kiuru-Kuhlefelt S, Larramendy ML, Lushnikova T, Monni O, Pere H, Tapper J, Tarkkanen M, Varis A, Wasenius VM, Wolf M, Zhu Y: DNA copy number losses in human neoplasms. Am J Pathol 1999, 155:683-694.

56. Perinchery G, Bukurov N, Nakajima K, Chang J, Hooda M, Oh BR, Dahiya R: Loss of two new loci on chromosome 8 (8p23 and 8q12-13) in human prostate cancer. Int J Oncol 1999, 14:495-500.

57. Young AN, Amin MB, Moreno CS, Lim SD, Cohen C, Petros JA, Marshall FF, Neish AS: Expression profiling of renal epithelial neoplasms: a method for tumor classification and discovery of diagnostic molecular markers. Am J Pathol 2001, 158:1639-1651.

58. Donald CD, Sun CQ, Lim SD, Macoska J, Cohen C, Amin MB, Young AN, Ganz TA, Marshall FF, Petros JA: Cancer-specific loss of beta-defensin 1 in renal and prostatic carcinomas. Lab Invest 2003, 83:501-505.

59. Wenghoefer M, Pantelis A, Dommisch H, Reich R, Martini M, Allam JP, Novak N, Berge $S$, Jepsen S, Winter J: Decreased gene expression of human beta-defensin-1 in the development of squamous cell carcinoma of the oral cavity. Int J Oral Maxillofac Surg 2008, 37:660-663

60. Joly S, Compton LM, Pujol C, Kurago ZB, Guthmiller JM: Loss of human beta-defensin 1, 2, and 3 expression in oral squamous cell carcinoma. Oral Microbiol Immunol 2009, 24:353-360.

61. Sun CQ, Arnold R, Fernandez-Golarz C, Parrish AB, Almekinder T, He J, Ho SM, Svoboda P, Pohl J, Marshall FF, Petros JA: Human beta-defensin-1, a potential chromosome $8 p$ tumor suppressor: control of transcription and induction of apoptosis in renal cell carcinoma. Cancer Res 2006, 66:8542-8549.

62. Bullard RS, Gibson W, Bose SK, Belgrave JK, Eaddy AC, Wright C, Hazen-Martin DJ, Lage JM, Keane TE, Ganz TA, Donald CD: Functional analysis of the host defense peptide Human Beta Defensin-1: new insight into its potential role in cancer. Mol Immunol 2008, 45:839-848.

63. Vahter M: Effects of arsenic on maternal and fetal health. Annu Rev Nutr 2009, 29:381-399.

64. de la Fuente H, Portales-Perez D, Baranda L, Diaz-Barriga F, Saavedra-Alanis $V$, Layseca E, Gonzalez-Amaro R: Effect of arsenic, cadmium and lead on the induction of apoptosis of normal human mononuclear cells. Clin Exp Immunol 2002, 129:69-77.

65. Rocha-Amador DO, Calderon J, Carrizales L, Costilla-Salazar R, Perez-Maldonado IN: Apoptosis of peripheral blood mononuclear cells in children exposed to arsenic and fluoride. Environ Toxicol Pharmacol 2011, 32:399-405. 
66. Thompson CB: Apoptosis in the pathogenesis and treatment of disease. Science 1995, 267:1456-1462.

67. Soto-Pena GA, Luna AL, Acosta-Saavedra L, Conde P, Lopez-Carrillo L, Cebrian ME, Bastida M, Calderon-Aranda ES, Vega L: Assessment of lymphocyte subpopulations and cytokine secretion in children exposed to arsenic. Faseb J 2006, 20:779-781.

68. Schofer H, Roder C: Hautarzt. Kaposi sarcoma in Caucasian women. Clinical, chemical laboratory and endocrinologic studies in 8 women with HIVassociated or classical Kaposi sarcoma 1995, 46:632-637.

69. Wikby A, Maxson P, Olsson J, Johansson B, Ferguson FG: Changes in CD8 and CD4 lymphocyte subsets, T cell proliferation responses and non-survival in the very old: the Swedish longitudinal OCTO-immune study. Mech Ageing Dev 1998, 102:187-198.

70. Hernberg M, Turunen JP, Von Boguslawsky K, Muhonen T, Pyrhonen S: Prognostic value of biomarkers in malignant melanoma. Melanoma Res 1998, 8:283-291.

71. Zhan $Y, X u Y$, Lew AM: The regulation of the development and function of dendritic cell subsets by GM-CSF: more than a hematopoietic growth factor. Mol Immunol 2012, 52:30-37.

72. Luna AL, Acosta-Saavedra LC, Lopez-Carrillo L, Conde P, Vera E, De Vizcaya-Ruiz A, Bastida M, Cebrian ME, Calderon-Aranda ES: Arsenic alters monocyte superoxide anion and nitric oxide production in environmentally exposed children. Toxicol Appl Pharmacol 2010, 245:244-251.

73. Pineda-Zavaleta AP, Garcia-Vargas G, Borja-Aburto VH, Acosta-Saavedra LC, Calderon-Aranda ES, Cebrian ME, Gomez-Munoz A, Vera Aguilar E: Nitric oxide and superoxide anion production in monocytes from children exposed to arsenic and lead in region Lagunera, Mexico. Toxicol Appl Pharmacol 2004, 198:283-290.

74. Concha G, Vogler G, Lezcano D, Nermell B, Vahter M: Exposure to inorganic arsenic metabolites during early human development. Toxicol Sci 1998, 44:185-190.

75. Rahman A, Vahter M, Ekstrom EC, Rahman M, Golam Mustafa AH, Wahed MAI, Yunus M, Persson LA: Association of arsenic exposure during pregnancy with fetal loss and infant death: a cohort study in Bangladesh. Am J Epidemiol 2007, 165:1389-1396.

76. Rahman A, Persson LA, Nermell B, El Arifeen S, Ekstrom EC, Smith AH, Vahter M: Arsenic exposure and risk of spontaneous abortion, stillbirth, and infant mortality. Epidemiology 2010, 21:797-804.

77. Raqib R, Ahmed S, Sultana R, Wagatsuma Y, Mondal D, Hoque AM, Nermell B, Yunus M, Roy S, Persson LA, Arifeen SE, Moore S, Vahter M: Effects of in utero arsenic exposure on child immunity and morbidity in rural Bangladesh. Toxicol Lett 2009, 185:197-202.

78. Rahman A, Vahter M, Ekstrom EC, Persson LA: Arsenic exposure in pregnancy increases the risk of lower respiratory tract infection and diarrhea during infancy in Bangladesh. Environ Health Perspect 2011, 119:719-724.

79. Ahmed S, Raqib R, Vahter M, Ekstrom EC, Moore S, Ameer SS, Gardner RM, Rekha RS, Mahabbat-e Khoda S: Arsenic-associated oxidative stress, inflammation, and immune disruption in human placenta and cord blood. Environ Health Perspect 2011, 119:258-264.

80. Ahmed S, Ahsan KB, Kippler M, Mily A, Wagatsuma Y, Hoque AM, Ngom PT, El Arifeen S, Raqib R, Vahter M: In utero arsenic exposure is associated with impaired thymic function in newborns possibly via oxidative stress and apoptosis. Toxicol Sci 2012, 129:305-314.

81. Andrew AS, Bernardo V, Warnke LA, Davey JC, Hampton T, Mason RA, Thorpe JE, Ihnat MA, Hamilton JW: Exposure to arsenic at levels found inU.S. drinking water modifies expression in the mouse lung. Toxicol Sci 2007, 100:75-87.

82. Kozul CD, Hampton TH, Davey JC, Gosse JA, Nomikos AP, Eisenhauer PL, Weiss DJ, Thorpe JE, Ihnat MA, Hamilton JW: Chronic exposure to arsenic in the drinking water alters the expression of immune response genes in mouse lung. Environ Health Perspect 2009, 117:1108-1115.

83. Mattingly $\mathrm{CJ}$, Hampton TH, Brothers KM, Griffin NE, Planchart A: Perturbation of defense pathways by low-dose arsenic exposure in zebrafish embryos. Environ Health Perspect 2009, 117:981-987.

84. Hermann AC, Kim CH: Effects of arsenic on zebrafish innate immune system. Mar Biotechnol (NY) 2005, 7:494-505.

85. Nayak AS, Lage CR, Kim CH: Effects of low concentrations of arsenic on the innate immune system of the zebrafish (Danio rerio). Toxicol Sci 2007, 98:118-124.

86. Xia $Y$, Hao G, Yang $Y$ : [Study on reproductive and immune toxicity of male rats exposed to As2O3]. Wei Sheng Yan Jiu 2009, 38:720-722.
87. Flora SJ, Kumar P: Biochemical and immunotoxicological alterations following repeated gallium arsenide exposure and their recoveries by meso-2,3-dimercaptosuccinic acid and 2,3-dimercaptopropane 1-sulfonate administration in rats. Environ Toxicol Pharmacol 1996, 2:315-320.

88. Schulz H, Nagymajtenyi L, Institoris L, Papp A, Siroki O: A study on behavioral, neurotoxicological, and immunotoxicological effects of subchronic arsenic treatment in rats. J Toxicol Environ Health A 2002, 65:1181-1193.

89. Sikorski EE, Burns LA, Stern ML, Luster MI, Munson AE: Splenic cell targets in gallium arsenide-induced suppression of the primary antibody response. Toxicol Appl Pharmacol 1991, 110:129-142.

90. Ghosh D, Bhattacharya S, Mazumder S: Perturbations in the catfish immune responses by arsenic: organ and cell specific effects. Comp Biochem Physiol C Toxicol Pharmacol 2006, 143:455-463.

91. Aggarwal M, Naraharisetti SB, Dandapat S, Degen GH, Malik JK: Perturbations in immune responses induced by concurrent subchronic exposure to arsenic and endosulfan. Toxicology 2008, 251:51-60.

92. Soto-Pena GA, Vega L: Arsenic interferes with the signaling transduction pathway of T cell receptor activation by increasing basal and induced phosphorylation of Lck and Fyn in spleen cells. Toxicol Appl Pharmacol 2008, 230:216-226.

93. Ghosh D, Datta S, Bhattacharya S, Mazumder S: Long-term exposure to arsenic affects head kidney and impairs humoral immune responses of Clarias batrachus. Aquat Toxicol 2007, 81:79-89.

94. Sikorski EE, McCay JA, White KL Jr, Bradley SG, Munson AE: Immunotoxicity of the semiconductor gallium arsenide in female B6C3F1 mice. Fundam Appl Toxicol 1989, 13:843-858.

95. Burchiel SW, Mitchell LA, Lauer FT, Sun X, McDonald JD, Hudson LG, Liu KJ: Immunotoxicity and biodistribution analysis of arsenic trioxide in C57BI/ 6 mice following a 2-week inhalation exposure. Toxicol Appl Pharmacol 2009, 241:253-259.

96. Blakley BR, Sisodia CS, Mukkur TK: The effect of methylmercury, tetraethyl lead, and sodium arsenite on the humoral immune response in mice. Toxicol Appl Pharmacol 1980, 52:245-254.

97. Nain S, Smits JE: Pathological, immunological and biochemical markers of subchronic arsenic toxicity in rats. Environ Toxicol 2010, 4:244-254.

98. Burns LA, Munson AE: Reversal of gallium arsenide-induced suppression of the antibody-forming cell response by vehicle supernatants. II. Nature and identification of reversing factors. J Pharmacol Exp Ther 1993, 265:150-158.

99. Patterson R, Vega L, Trouba K, Bortner C, Germolec D: Arsenic-induced alterations in the contact hypersensitivity response in Balb/c mice. Toxicol Appl Pharmacol 2004, 198:434-443.

100. Savabieasfahani M, Lochmiller RL, Rafferty DP, Sinclair JA: Sensitivity of wild cotton rats (Sigmodon hispidus) to the immunotoxic effects of low-level arsenic exposure. Arch Environ Contam Toxicol 1998, 34:289-296.

101. Arkusz J, Stanczyk M, Lewiniska D, Stepnik M: Modulation of murine peritoneal macrophage function by chronic exposure to arsenate in drinking water. Immunopharmacol Immunotoxicol 2005, 27:315-330.

102. Chakraborty S, Ray M, Ray S: Evaluation of phagocytic activity and nitric oxide generation by molluscan haemocytes as biomarkers of inorganic arsenic exposure. Biomarkers 2009, 14:539-546.

103. Sengupta M, Bishayi B: Effect of lead and arsenic on murine macrophage response. Drug Chem Toxicol 2002, 25:459-472.

104. Lantz RC, Parliman G, Chen GJ, Carter DE: Effect of arsenic exposure on alveolar macrophage function. I. Effect of soluble as(III) and as(V). Environ Res 1994, 67:183-195.

105. Bishayi B, Sengupta M: Intracellular survival of Staphylococcus aureus due to alteration of cellular activity in arsenic and lead intoxicated mature Swiss albino mice. Toxicology 2003, 184:31-39.

106. Sikorski EE, Burns LA, McCoy KL, Stern M, Munson AE: Suppression of splenic accessory cell function in mice exposed to gallium arsenide. Toxicol Appl Pharmacol 1991, 110:143-156.

107. Yan S, Zhang QY, Zhou B, Xue L, Chen H, Wang Y, Zheng SS: Arsenic trioxide attenuated the rejection of major histocompatibility complex fully-mismatched cardiac allografts in mice. Transplant Proc 2009, 41:1855-1858.

108. Kavian N, Marut W, Servettaz A, Laude H, Nicco C, Chereau C, Weill B, Batteux F: Arsenic trioxide prevents murine sclerodermatous graft-versus-host disease. J Immunol 2012, 188:5142-5149. 
109. Escudero-Lourdes C, Martinez FD, Calvillo RQ, Medina de la Garza CE: Effect of oral chronic intoxication with sodium arsenite on murine giardiasis. Proc West Pharmacol Soc 2005, 48:92-99.

110. Kozul CD, Ely KH, Enelow RI, Hamilton JW: Low-dose arsenic compromises the immune response to influenza A infection in vivo. Environ Health Perspect 2009, 117:1441-1447.

111. Lin-fu Z, Kai-sheng Y, Zhi-min Z: Role of low dosage arsenic trioxide on pulmonary dendritic cells in asthmatic mice. Chin J Integr Med 2003, 9:281-284.

112. Zhang L, Li K, Bing Ma L, Gong SB, Wang GY, Liu Y, Ji XY, Xu L, Liu SK, Chen P, Ouyang RY, Xiang XD: Effects and mechanism of arsenic trioxide on reversing the asthma pathologies including Th17-IL-17 axis in a mouse model. Iran J Allergy Asthma Immunol 2012, 11:133-145.

113. Martin-Chouly C, Morzadec C, Bonvalet M, Galibert MD, Fardel O, Vernhet L: Inorganic arsenic alters expression of immune and stress response genes in activated primary human T lymphocytes. Mol Immunol 2011, 48:956-965.

114. Morzadec C, Bouezzedine F, Macoch M, Fardel O, Vernhet L: Inorganic arsenic impairs proliferation and cytokine expression in human primary T lymphocytes. Toxicology 2012, 300:46-56.

115. Conde P, Acosta-Saavedra LC, Goytia-Acevedo RC, Calderon-Aranda ES: Sodium arsenite-induced inhibition of cell proliferation is related to inhibition of IL-2 mRNA expression in mouse activated T cells. Arch Toxicol 2007, 81:251-259.

116. Cho Y, Ahn KH, Back MJ, Choi JM, Ji JE, Won JH, Fu Z, Jang JM, Kim DK: Age-related effects of sodium arsenite on splenocyte proliferation and Th1/Th2 cytokine production. Arch Pharm Res 2012, 35:375-382.

117. Das S, Pan D, Bera AK, Rana T, Bhattacharya D, Bandyapadyay S, De S, Sreevatsava V, Bhattacharya S, Das SK, Bandyopadhayay S: Sodium arsenite mediated immuno-disruption through alteration of transcription profile of cytokines in chicken splenocytes under in vitro system. Mol Biol Rep 2011, 38:171-176.

118. Frouin H, Fortier M, Fournier M: Toxic effects of various pollutants in 11 B7501 lymphoma B cell line from harbour seal (Phoca vitulina). Toxicology 2010, 270:66-76

119. McCabe M, Maguire D, Nowak M: The effects of arsenic compounds on human and bovine lymphocyte mitogenesis in vitro. Environ Res 1983, 31:323-331.

120. Morzadec C, Macoch M, Robineau M, Sparfel L, Fardel O, Vernhet L: Inorganic arsenic represses interleukin-17A expression in human activated Th17 lymphocytes. Toxicol Appl Pharmacol 2012, 262:217-222.

121. Macoch M, Morzadec C, Fardel O, Vernhet L: Inorganic arsenic impairs differentiation and functions of human dendritic cells. Toxicol Appl Pharmacol 2013, 266:204-213.

122. Tenorio EP, Saavedra R: Differential effect of sodium arsenite during the activation of human CD4+ and CD8+ T lymphocytes. Int Immunopharmacol 2005, 5:1853-1869.

123. Binet F, Antoine F, Girard D: Interaction between arsenic trioxide and human primary cells: emphasis on human cells of myeloid origin. Inflamm Allergy Drug Targets 2009, 8:21-27.

124. Bustamante J, Dock L, Vahter M, Fowler B, Orrenius S: The semiconductor elements arsenic and indium induce apoptosis in rat thymocytes. Toxicology 1997, 118:129-136.

125. Harrison MT, McCoy KL: Immunosuppression by arsenic: a comparison of cathepsin L inhibition and apoptosis. Int Immunopharmacol 2001, 1:647-656.

126. Lemarie A, Morzadec C, Merino D, Micheau O, Fardel O, Vernhet L: Arsenic trioxide induces apoptosis of human monocytes during macrophagic differentiation through nuclear factor-kappaB-related survival pathway down-regulation. J Pharmacol Exp Ther 2006, 316:304-314.

127. Gonzalez-Rangel Y, Portales-Perez DP, Galicia-Cruz O, Escudero-Lourdes C: Chronic exposure to arsenic sensitizes CD3+ and CD56+ human cells to sodium arsenite-mediated apoptosis. Proc West Pharmacol Soc 2005, 48:89-91.

128. Yoshida T, Shimamura T, Shigeta S: Enhancement of the immune response in vitro by arsenic. Int J Immunopharmacol 1987, 9:411-415.

129. Li Q, Lauer FT, Liu KJ, Hudson LG, Burchiel SW: Low-dose synergistic immunosuppression of T-dependent antibody responses by polycyclic aromatic hydrocarbons and arsenic in C57BL/6J murine spleen cells. Toxicol Appl Pharmacol 2010, 245:344-351.

130. Lemarie A, Morzadec C, Bourdonnay E, Fardel O, Vernhet L: Human macrophages constitute targets for immunotoxic inorganic arsenic. J Immunol 2006, 177:3019-3027.
131. Sakurai T, Ohta T, Tomita N, Kojima C, Hariya Y, Mizukami A, Fujiwara K Evaluation of immunotoxic and immunodisruptive effects of inorganic arsenite on human monocytes/macrophages. Int Immunopharmacol 2006, 6:304-315.

132. Wang $L$, Weng CY, Wang YJ, Wu MJ: Lipoic acid ameliorates arsenic trioxide-induced HO-1 expression and oxidative stress in THP-1 monocytes and macrophages. Chem Biol Interact 2011, 190:129-138.

133. Bourdonnay E, Morzadec C, Fardel O, Vernhet L: Redox-sensitive regulation of gene expression in human primary macrophages exposed to inorganic arsenic. J Cell Biochem 2009, 107:537-547.

134. Bourdonnay E, Morzadec C, Sparfel L, Galibert MD, Jouneau S, Martin-Chouly C, Fardel O, Vernhet L: Global effects of inorganic arsenic on gene expression profile in human macrophages. Mol Immunol 2009, 46:649-656.

135. Bomberger JM, Coutermarsh BA, Barnaby RL, Stanton BA: Arsenic promotes ubiquitinylation and lysosomal degradation of cystic fibrosis transmembrane conductance regulator (CFTR) chloride channels in human airway epithelial cells. J Biol Chem 2012, 287:17130-17139.

136. Shaw JR, Bomberger JM, VanderHeide J, LaCasse T, Stanton S, Coutermarsh B, Barnaby R, Stanton BA: Arsenic inhibits SGK1 activation of CFTR Clchannels in the gill of killifish, Fundulus heteroclitus. Aquat Toxicol 2010, 98:157-164.

137. Olsen CE, Liguori AE, Zong Y, Lantz RC, Burgess JL, Boitano S: Arsenic upregulates MMP-9 and inhibits wound repair in human airway epithelial cells. Am J Physiol Lung Cell Mol Physiol 2008, 295:L293-302.

138. Sherwood CL, Lantz RC, Burgess JL, Boitano S: Arsenic Alters ATP-Dependent Ca2+ Signaling in Human Airway Epithelial Cell Wound Response. Toxicol Sci 2011, 121:191-206.

139. Josyula AB, Poplin GS, Kurzius-Spencer M, McClellen HE, Kopplin MJ, Sturup S, Clark Lantz R, Burgess JL: Environmental arsenic exposure and sputum metalloproteinase concentrations. Environ Res 2006, 102:283-290.

140. Lantz RC, Hays AM: Role of oxidative stress in arsenic-induced toxicity. Drug Metab Rev 2006, 38:791-804.

141. Lantz RC, Lynch BJ, Boitano S, Poplin GS, Littau S, Tsaprailis G, Burgess JL: Pulmonary biomarkers based on alterations in protein expression after exposure to arsenic. Environ Health Perspect 2007, 115:586-591.

doi:10.1186/1476-069X-12-73

Cite this article as: Dangleben et al: Arsenic immunotoxicity: a review. Environmental Health 2013 12:73.

\section{Submit your next manuscript to BioMed Central and take full advantage of:}

- Convenient online submission

- Thorough peer review

- No space constraints or color figure charges

- Immediate publication on acceptance

- Inclusion in PubMed, CAS, Scopus and Google Scholar

- Research which is freely available for redistribution 